声帯の自励振動モデルと計算機シミュレーション

石坂謙 三

\title{
On Self-oscillating Models of the Vocal Cords and its Computer Simulation
}

\author{
Kenzo Ishizaka
}

\begin{abstract}
This paper discusses models of the vocal cords, which can be categorized into a drivingpoint impedance (or terminal) type and a multi-mass system type. The former typically invoJves a so-called one-mass model and also a two-mass model of the vocal cords, and the latter represents the difference approximation of motion equations and also the finite element method. Models for the air flow through the larynx are also considered in connection with the models of the vocal cords.

The mechanism of self-excited oscillation of the vocal cords is described in terms of the degeneration of natural modes of vibration which results from the glottal flow. The intention is to clarify the distinction between the self-excited oscillation and the free oscillation of the vocal cords.

A self-excited oscillator inherently involves some of non-linear factors with respects to the amplitude of oscillation. In the vocal-cord oscillator, they are the collision of the bilateral vocal cords, the non-linear elasticity of cord tissue, and the non-linearity in the aerodynamics. These non-linear factors must properly be involved in the computer models of the vocal cords. Finally, general cosiderations of the computer simulation of cord-vibration are discussed.
\end{abstract}

\section{I.はじめに}

粘膜波状運動が声帯の自励振動機構において, 本質的 役割を果たしていることを説いた広戸の mucoviscoelastic aerodynamic theory ${ }^{11}$ が提唱されたのは1966年であ るが，工学分野に扔いてもこの前後に日本 (電通大), 米国 (M.I.T., Bell Labs.) において, 互いに独立に声帯 の自励振動機構に関する研究が進められていた。この研 究の直接の目的は, 空気一声帯の相互作用による声帯の 自励振動機構を数理的に解明し, これを音声生成理論, 音声生成モデルに組み入れることにあったといえる。粘 弾性組織より成る声帯の三次元の複雑な形状と, それに

電気通信大学通信工学科
よって形成される声門を流れる空気流を，数理的に扱う のは極めて困難であるため, 声帯をモデル化して表し, これを主として電子計算機によって数值的に解くことに よって, この研究は進められてきた.

すなわち, 上下声唇の位相差を伴ら振動モードを近似 しうる, もっとも簡単なモデルとして 2 自由度モデル （以下 2 質量モデルといら）が提案され，これによって 広戸の説における粘膜波状運動の声帯の自励振動におけ る意義が, 数理的に明らかになるとともに ${ }^{2)}$, 声門面積 波形, 声門体積流波形, ピッチ周波数と呼気圧の関係, 声道の音響的負荷に対する声帯振動の依存性などの, 本 計算機モデルの諸動作特性が, 声帯の実際の動作特性と よく一致することが, 計算機シュレーションによって確 かめられた ${ }^{3)}$. さらに, 本モデルは声道の計算機モデル 
に組み込まれて, 動的音声合成装置が作られた. その結 果, 呼気圧, 声門の静止位置, 声帯の緊張度および声道 の面積関数より成る生理的パラメータより, 実際の音声 生成機構に則して自然性に富む, 高品質な音声が合成で きるよらになった

その後, 粘膜波状運動をさらに堀り下げて, 平野は声 帯組織の層構造（cover-body 構造）と, その弾性特性 を明らかにしてきだ). この研究に対応して，声帯を多 数の小区分要素に分割したモデル, すなわち声帯組織内 部の運動をも, 直接計算しようとする計算機モデルの研 究が行われている7,8).

以上のように, 色々な声带モデルによる計算機シミュ レーションが発表されているが，各モデルは当然それぞ れの目的を持っている. 本論文では, 統一的観点よりこ れらモデルの意図するところ, 特長, および問題点を論 ずる.また，声帯振動を数理的に扱った論文の中には， 自励振動と自由振動を混同して議論しているのもあるの で，この両者の差異を具体的に述べる. ついで, 両側声 帯の衝突，および非線形弾性特性を計算機モデルに適切 に組み入れることの必要性を述べる. 最後に, 声帯振動 の計算機シミュレーションについて考慮すべき点, また いかなる問題点があるか述べてみたい。

\section{II. 声 帯 モ デル}

声帯の運動を記述する運動方程式と, 声門を流れる空 気の運動を記述する運動方程式は, 互いに結合した連立 方程式である. これらの式を声帯の変位, 空気の流速に ついて解けば, 声帯の自励振動が時間の関数として求め られる.ここに自励振動とは, 声帯振動の周期に対応寸 る周期的外部励振なしに, 肺から供給される直流 (非周 期的）エネルギーによって生起し，持続する周期的振動 をいう. 声帯の形状が複雑であり, 声帯の粘弾性特性も また異方性不均質媒体であるため, 声帯の運動を数理的 に記述し, 解を求めるためには, 声帯をモデル化するこ とが必要である. 同じく, 声門の気流，圧力分布につい てもモデル化が必要である.たとえば, van den Berg は声門を細長い矩形断面の平行間陌によって近似し, 声 門内の流れを一次元流とみなして, 気流の声門抵抗と声 門内压力分布の奏験式を求めている ${ }^{9)}$. これは声門空気 系の1つのモデルである.

これまでに発表されている声帯のモデルは，大別する と次の 2 つの形に分類することができる.

(1) 気流圧力が作用する声帯の端面からみた，声帯の 駆動点インピーダンスによって, 声带の振動特性を記述 する方式（これを以下駆動点インピーダンス形モデルと
呼ぶ).

(2) 声帯組織内部の各質点の運動を直接記 述する方 式. これを多質点系モデルと呼ぶことにする. 声帯を連 続体（あるいは分布定数系）として扱って, 偏微分方程 式によって運動を記述しても，計算機によって数值解を 求める時には, 差分方程式によって近似する. この近似 差分方程式は離散的な質点系の運動を記述するものであ るから，いわゆる連続体モデルもこの分類に入る.

\section{1. 眍動点インピーダンス型モデル}

気流に面した声帯端面に作用する力によって，声帯表 面がどのように振動するかがわかれば（すなわち，駆動 点インピーダンスがわかれば)，声帯組織内部の 運動は 必ずしも計算する必要はなく，気流との相互作用による 声带表面の運動を求めることができる．上下声唇の位相 差を無視して，声帯端面が同一位相で一様に振動するも のと仮定する場合には，一側の声帯を集中的な等価質 量, 等価スチフネスおよび等価抵抗より成る，1つの振 動子によって等価表示することができる.これが，いわ ゆる 1 質量モデルである. ここにいう等価質量とは, 声 帯モデルの質量が実際の声帯の端面と同じ振幅で振動す るとき，声帯モデルの運動エネルギーが，実際の声帯の 全運動エネルギーと等しくなるような質量をいう．等価 スチフネスについても, 同じ条件において声帯モデルの 位置エネルギーが，実際の声帯の全位置エネルギーと等 しくなるように選ばれたスチフネスをいう.

次に，上下声唇の位相差を伴った振動モードを表すた めの第 1 近似モデルが，いわゆる 2 自由度モデル（以下 2 質量モデルといら）である. 一般に，この形のモデル の等価定数の值は, 声帯内部の振動分布がわからないと 厳密には定めることができないが，ある程度の仮定を設 けることによって，これらの等価定数值を推定すること ができる.また, 駆動点インピーダンス（等 価定数） は，声帯端面（駆動点）から測定可能である．あるいは また，外部から測定可能な量，たとえば声帯粘膜の移動 性と駆動点インピーダンスを関倸付けることも可能であ ろら.上述のよらに, この形のモデルは気流と相互作用 する声帯端面の振動特性に着目しているのであって，た とえば 2 質量モデルにおいては, 結合スチフネスによっ て組み合わされた 2 組の振動子によって，声帯端面の振 動特性を表しているが，これは声帯の内部組織を，たと えば粘膜層と筋肉組織に直接対応させて，2つの質量に 区分しているのではない.

この形のモデルは，気流と相互作用する声帯端面の動 作を記述するものであるから, 当然声帯の自励振動機構 を表すことができ，計算機モデルの動作特性，振動モー 
Vol. 22 No. $3,1981.7$

ド，声門面積波形，声門体積流波形などは実際と一致す るはずである.すなわち，この形のモデルの特長は，声 帯組織内部の運動を計算することなく，上述の声帯の諸 動作特性を求められることである．したがってモデルが 簡単となり，後述の多質点系モデルと比べて計算時間が 著しく短くてすむこと, さらに 2 質量モデル程度の簡単 なモデルであれば，自励振動条件を解析的に求めること ができ, 声帯の自励振動機構の理解が見通しょく得られ ることである.このよらな特長のため, この形のモデル は自励振動機構の解明のために使用され，また音声合成 における声帯音源モデルとして用いられている3

\section{2. 多質点系モデル}

上述のように, この形のモデルは声帯組織内部の振動 を直接記述し，これを数值計算によって解くものであ る.この形に属するものとしては, 二次元であるが声帯 断面を多数の三角形要素に分割して表した朱雀 (1971) の有限要素法によるモデル7)，さらに最近では声帯を 4 $\times 4 \times 4$ 要素に分割した Titze（1979）の三次元モデル がある ${ }^{8)}$.

Titze のモデルでは, 声帯を連続体としてその運動を 偏微分方程式によって記述し，これを差分方程式によっ て近似して逐次数值計算を行う.この差分近似と計算精 度について簡単に補足する. 運動方程式は双曲型偏微分 方程式である. 一般にこの場合に, 差分近似によって安 定な解が得られるためには, 空間座標の間隔 $\Delta \mathrm{x}$ 之計算 の時間ステップ（サンプリング周期） $\Delta \mathrm{t}$ との間には, 次の安定条件がみたされなければならない。

$$
\mathrm{Cp}^{2}\left(\frac{\Delta \mathrm{t}}{\Delta \mathrm{x}}\right)^{2}<\left[1+\frac{\mathrm{Cs}^{2}}{\mathrm{Cp}^{2}}\right]^{-1}
$$

ただし二次元で $2 つ の$ 空間座標の間隔は共に $\Delta \mathrm{x}$ とす る.また $\mathrm{Cp}, \mathrm{Cs}$ はとれぞれ声帯媒体を伝播する縦波, 横波の速度である. $\mu$ を横弾性係数, $\lambda$ を体積弾性倸 数, $\rho$ を密度とすると, $\mathrm{Cp} \simeq[(\lambda+2 \mu) / \rho]^{1 / 2}, \mathrm{Cs} \simeq$ $(\mu / \rho)^{1 / 2}$ である. 声帯の場合にはだいたい, $\lambda \simeq 2.6 \times$ $10^{10} \mathrm{dyn} / \mathrm{cm}^{2}, \mu \simeq 2.5 \times 10^{4} \mathrm{dyn} / \mathrm{cm}^{2}, \rho \simeq 1.1 \mathrm{~g} / \mathrm{cm}^{3}$ であるから ${ }^{16)}, \Delta \mathrm{x}$ を $0.1 \mathrm{~cm}$ オーダで計算すると, サ ンプリング周波数は $1 / \Delta \mathrm{t} \approx 10^{6} \mathrm{~Hz}=1 \mathrm{MHz}$ オーダとな る. 2 質量モデルのサンプリング周波数 $(1 / \Delta \mathrm{t})$ が 10 $\mathrm{kHz}$ で十分であるのと比べると, この場合の所要サン プリング周波数は 2 桁も高く, その上振動を計算すべき 質点の数が $4 \times 4 \times 4$ 点と格段に多いのであるから, 差 分近似による多質点系モデルの所要計算時間は膨大なも のとなる.この点については, 後述の計算機シミュレー ションの項でさらに具体的に述べる.

声帯組織の粘弹性の異方性, 不均質性, 大振幅非線形
特性,さらに両側声帯の衝乫などを多質点系モデルに組 み入れることは，必要欠くべからざることであるが，こ のためには有限要素法が適している. それゆえ, 今後は 有限要素法によるモデル化, 計算機シミュレーションが 進められることと思われる. 朱雀のモデル (1971) $)^{7}$ は, 二次元ではあったが，有限要素法を声帯に適用した最初 のものである. 当時は, いまだ cover-body 構造が現在 ほど明確に指摘されていなかったためと思われるが，声 帯組織を均質とみなし，また van den Berg の声門抵 抗，圧力分布の実験式）を基本的に使用しているなどの 問題点はあるが，このモデルの研究が継続されなかった のは惜しまれる。

要約すると, この形のモデルは声帯を多数の質点系で 表し, 声帯の基本的粘弹性定数を用いて各質点の運動を 数值計算によって求めることに特長がある. その代価と して，多大な計算時間を要する．なお，現在のモデルは 線形モデルであるが，これに非線形粘弾性特性を組み込 むこと，一般的な場合を含めて両側声帯の衝突をらまく 扱らことが今後の課題であろう.また，多質点系モデル によって声帯各部の運動が詳細に記述されるとき，それ に応じて声門形状が複雑となるが，この場合の流体系の モデル，すなわち声門の流体インピーダンス，圧力分布 をいかに扱らかという困難な問題がある.

\section{III. 声門の空気系モデル}

van den Berg が声門抵抗を測定するのに用いた喉頭 のモデル9)のように, 声門を細長い矩形断面の平行間隙 と仮定しても, 声帯が開閉運動しているときの, いわゆ る非定常流の声門インピーダンスを理論的に求めること は不可能である. したがって, 従来の計算機シミュレー ションに㧧いては，各サンプリング時間毎に流れは定常 状態にあるとみなす，いわゆる準定常流の仮定のもとに 流れを計算している、ところが，このように簢単な矩形 平行間隙の定常流を仮定しても，なお声門抵抗を純理論 的に求めることはできない。それゆえ, van den Berg は喉頭モデルを用いて声門抵抗, 圧力分布の実験式を求 めているのである. しかしながら, 彼の求めた声門抵抗 の実験式は比較的妥当な流速值を与えるが，声門内圧力 分布については過大な負圧力(いわゆる Bernoulli の陰 圧）を与え適切でないことが，理論的検討によって明ら かになっている ${ }^{10)}$. 1 質量モデルを含む 2 質量モデルの 声門抵抗, および圧力分布のより精度の高い近似式が筆 者らによって与えられている3,10).

多質点系モデルにおいて, 声門下腔および声門が複雑 な三次元形状をとるときの声門抵抗，圧力分布は極めて 
難しい問題である.多くの仮定のもとに近似式を使用す ることになろらが，この場合には流体系モデルの十分な 吟味が必要である，たとえば, ある流体系モデルと，多 質点系モデルによる計算機シミュレーションによって, 仮りに声带モデルが笑際に近い振動モードで自励振動し たとしても，その流体系モデルが妥当であるかははなは だ疑問である.この場合, 計算機モデルの振動の一周期 中のいくつかの位相における, 各声門形状に対する定常 流の流速, 圧力分布を数值計算によって求め, この結果 を同一形状の声帯模型による実測によって比較, 検討す る位の科学的厳密さが必要と思われる. このように流体 系の数理的扱いを困難にしているのは, 流体の運動を記 述する Navier-Stokes の式が非線形のためである.

\section{IV. 自励振動と自由振動}

振動体が何らの外力をらけず, 自由に振動するとき, これを自由振動という. 自由振動モードおよび固有周波 数は一般に多数存在する. 一般に線形の弾性体の外部駆 動力による強制振動は, 外部駆動力によって励振され る自由振動モードの線形の組み合わせによって記述され る. 声帯の自励振動の場合には, 周期的外部駆動力は存 在せず, 声带の運動変位によって（声門間隙が変化し） 気流および声門圧力が変化し, この圧力変化が声帯に反 作用して, さらに声帯の運動を助勢するといら閉じた ループを形成していて, 強制振動の場合とは異なる. 以下に 2 質量モデルによってこの差異を具体的に述べ る.

2 質量モデルは（気流がないとき），2つの自由振動 モードを持っている. 換言すると, 実際の声帯の持って いる多数の自由振動モードの中の，固有周波数の低い方

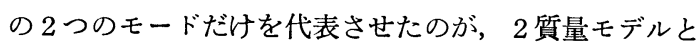
いえる(この観点より当初は 2 自由度モデルと名付けら れた). 固有周波数 $\left(\mathrm{f}_{10}\right)$ の低い方のモードは, 上下声 唇が同一位相で一様に振動するモード(これを10モード と呼ぶ）であり，固有周波数（ $\mathrm{f}_{11}$ ) が高い方のモード は，上下声唇が互いに逆位相で振動するモード（11モー

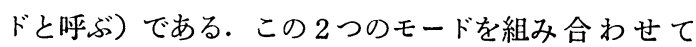
も, 一般に $\mathrm{f}_{10}$ と $\mathrm{f}_{11}$ とが等しくないため, 声帯の自励 振動モードとならないことは明らかである. 次に, 声門 に気流を流し，しだいに流速を増大すると，2つのモー ドは変わらないが，固有周波数は気流による負スチフネ スの效果によって変化する. $f_{10}$ の流速による変化は比 較的少ないが, $\mathrm{f}_{11}$ は流速の増大に伴って急速に低下し, ついには $\mathrm{f}_{11}$ は $\mathrm{f}_{10}$ と一致する(これを両モードの縮退 といら).この臨界流速以上では, 自励振動条件がみた
され， $\mathrm{f}_{10}=\mathrm{f}_{11}$ の関係が保たれ，声帯は自励振動を開始

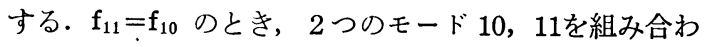
せると，声帯の自励振動モードが得られる．流速による モードの縮退が, 声带の自励振動機構の本質なのであ $ろ^{11,12)}$.

この点が理解されていないと，たとえば Titze (1976) の論文のように間違った議論がなされることになる ${ }^{13)}$. すなわち, 彼は声帯を矩形断面の細長い非圧縮性媒体之 みなし，この場合の自由振動モード，固有周波数を解析 的に求め, これに基づいて声帯の自励振動機構を論じて いる. このモデルの低次の 2 つの自由振動モードは上述 の10,11モードである. 当然両モードの固有周波数 $\mathrm{f}_{10}$, $\mathrm{f}_{11}$ は等しくない. ここでまず，2 質量モデルの計算機 シミュレーションの結果を検討して， $\mathrm{f}_{10}, \mathrm{f}_{11}$ のいずれ か低い方の周波数, モードで声帯は自励振動すると推論 し，これを前提とする（実際は上述のように，気流の負 スチフネス効果によって $\mathrm{f}_{11}$ が低下し，10モードに縮退

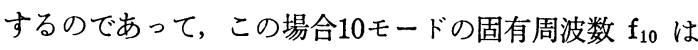
あまり気流の影響をうけないため, 自励振動周波数 $\mathrm{f}_{0}$ がほぼ $\mathrm{f}_{10}$ に等しいといらことである).ささらに，上下 声唇の位相差を伴った声帯の振動を11モードとみなし (これも間違いであって, 11モードの上下声唇の位相差 は $180^{\circ}$ である．実際は縮退した11モードと10モードの結 合が自励振動モードとなる), この11モードで自励振動 するためには, 上述の前提によって11モードの固有周波 数 $\mathrm{f}_{11}$ が $\mathrm{f}_{10}$ よりも低く,かつ $\mathrm{f}_{11}$ が実際の声帯の自励 振動の周波数範囲になければならないと彼は考えた。 そ して声带媒体を非圧縮性と考えると（声帯のポアソン比 $\sigma=\lambda /[2(\lambda+\mu)] \approx 1 / 2$ であるから，このこと自体は正 (い), $f_{11}<f_{10}$ となると述べている. すなわち, 気流の 作用を無視して，自由振動モードのみを考えて自励振動 を論じようとしているために，縮退による11モードと10 モードの結合が考えられず, 11モードを声帯の自励振動 モードとみなし，間違った議論を展開している。なお， 駆動点インピーダンス, あるいは等価質量, 等価スチフ ネスなどの值は自由振動の解析より求められる.

\section{V. 両側声帯の衝突および非線形弾性特性}

一般に自励振動系においては，振動振幅に対する何ら かの非線形特性によって, 振幅が制限されて定常振幅に 落ち着く. 声帯の場合におけるこのような非線形要因と しては, 両側声帯の衝突, 粘弾性の非線形大振幅特性 ${ }^{17)}$ および気流（声門間隙と流速，圧力分布）の非線形特性 があげられる.したがって, これら非線形要因を計算機 モデルに, 適切に組み込むことが必要である.非線形要 
因の効果は, 計算機シミュレーションによって定量的に しることができる.たとえば, 呼気圧による振動周波数 （あるいはピッチ周波数）の変化は, 弾性の非線形大振 幅特性と, 両側声帯の衝突によるものであることが， 2 質量モデルの計算機シミュレーションによって判明して いる3,11). Titze の多質点系形モデルでは，声帯の弾性 特性を線形と仮定しているため, 呼気圧によるピッチ周 波数の変化はないと述べている8. ただし，この場合で も, 呼気圧が $5 \sim 6 \mathrm{cmH}_{2} \mathrm{O}$ 以下では, 衝突に起因する ピッチ周波数の変化が生じるはずである.この変化も起 きないとすると, 衝突の扱いに問題があるのではないか と思われる.

左右対称振動の場合には, 衝突は必ず正中面で起こる から衝突の問題はかなり簡単化することが可能である. 病的な場合を含む左右非対称の一般的な場合の衝突は, 多質点系モデルにおいてはかなり厄介な問題となろら. なお，この場合については，2質量モデルによる一色と 筆者による研究があり ${ }^{14)}$, 計算機モデルの動作が，摘出 喉頭による実験結果とよく一致することが確かめられて いる.

\section{VI. 計算機シミュレーション}

上述のように， 1 質量モデル， 2 質量モデルの場合に は, 自励振動条件, 振動モードを解析的に求めることが 可能であるが，それでも声帯モデルと流体系との両運動 方程式を解析的に解き, 時間の関数として声帯の振動解 を求めることは不可能である. まして多質点系形モデル の場合には, 時間の関数としての振動解はもちろんのこ と, 自励振動条件すら解析的に求めることはできない. したがって，駆動点インピーダンス形モデル，多質点系 型モデルの両場合とも, 振動解は計算機によって数值解

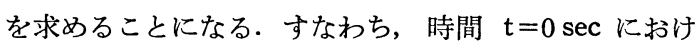
る初期条件を用いて，まず微小時間（サンプリング周 期, 典型的には0.1 0.05 msec) 後の流速, 圧力, 声帯 変位を計算し，これらの数值を用いてさらに次のサンプ リング時間における值を逐次数值計算によって求める. この場合に厄介なことは, 流速, 圧力と声帯変位が流体 系と声帯運動系を記述する複雑な, 非線形運動方程式に よって結ばれていることである.しかし，このような場 合の数值計算の基本的手法は, 1 質量モデルの計算機シ ミュレーションを最初に行った Flanaganによって与え られている14).

計算機シミュレーションは, 実際の物理的, 生理的実 験に代わる一種の数值的な実験といえる. 計算機シミュ レーションにおいては，たとえば声帯各部の 粘弾性定
数, あるいは呼気圧などの諸定数の值を自由に涠ぶこと ができ, この結果生ずる声帯各部の変位や流速, 圧力な どが数值的に求められることが大きな特長である.さら に, 必要に応じてこれらのデータを, シミュレーション と並列に計算機によって処理することができる．しか し, 計算機シミュレーションによって声帯の振動現象を 模擬し, 数值データが得られることと, その現象を理解 することが別なことは, 声帯の生理的実験や観測におけ ると同様である.たとえば, 多質点系形モデルによって 声帯各部の詳細なシミュレーションがなされたとして も，その計算結果から声帯の自励振動機構がすぐに明ら かになるわけでない. 現象の本質を抽象化することが必 要となる.

また, 声帯振動系のよらな複雑な系になると, その数 值計算の結果が数值的に正しいかどらかを, 数值を追っ て調べることは不可能であって, 計算機モデルの動作が 実際の声帯の諸動作と定量的に一致するか否かによっ て，モデルの適否とともに数值計算の妥当性を判定せざ るを得ないのである. したがって, 声帯モデルの動作特 性を実際の声帯の動作特性によって比較, 検討すること はもちろんであるが，さらに声帯モデルの弾性定数など の值を適当に選んで，これに相当する模型声 帯を製 作 し, 気流によって励振してその動作特性と比較, 検討す ることも必要と思われる.

さきに, 双曲型偏微分方程式を差分によって近似計算 する Titze のモデルにおいては，質点の座標間隔と波 動の伝播速度およびサンプリング周波数の間には, (1)式 の関係がみたされなければならないことを述べた.サン プリング周波数が，この関係よりはずれるときは計算精 度が急速に低下し，計算は収束せず発散するにいたる。 Titze の計算機シミュレーションにおいては, サンプリ ング周期を $\Delta \mathrm{t}=1 / \mathrm{c}$ にとって ( $\mathrm{c}$ は空気中の音速), 計 算誤差の推定を行っているが，一方計算が安定なために は $\lambda$ (体積弾性係数) の值に限界があると述べ， $\lambda$ の值 を $10^{6} \mathrm{dyn} / \mathrm{cm}^{2}$ にっている. この值は von Gierke ら の測定 ${ }^{16)}$ による生体組織の $\lambda$ の值 $2.6 \times 10^{10} \mathrm{dyn} / \mathrm{cm}^{2}$ と 比べると 4 桁も小さな值である. サンプリング周期を $\Delta \mathrm{t}=1 / \mathrm{c}$ に選ぶと（空気中の音速 $\mathrm{c}$ はこの場合何ら根拠 がないのであるが), $\Delta \mathrm{x}=0.05 \mathrm{~cm}$ にとっているから, (1)式をみたす $\lambda$ の值は $10^{6} \mathrm{dyn} / \mathrm{cm}^{2}$ のオーダと逆算さ れるが，これでは本末転倒であって，実際の值より入が 小さすぎて, シミュレーションの結果を信用しかねるこ とになる.

声道内を伝播する音波を記述する波動方程式も, 同じ く双曲型偏微分方程式である. これを単純に差分によっ 
である). たとえば, 簡単のため一次元の波動を考え, 声道を10区間に分割して計算するときは，声道の全長を $17 \mathrm{~cm}$ とすると, $\Delta \mathrm{x}=1.7 \mathrm{~cm}$ であるから所要サンプリ ング周波数は $1 / \Delta \mathrm{t} \geq \mathrm{c} / \Delta \mathrm{x} \fallingdotseq 20 \mathrm{kHz}$ となる.

一方， 1 質量モデルあるいは 2 質量モデル自体の，所 要サンプリング周波数は $10 \mathrm{kHz}$ 程度であるから, これ らの声帯モデルに10セクションの声道モデルを結合した 場合には, 声道の計算に所要とされる高い方のサンプリ ング周波数, $20 \mathrm{kHz}$ で声帯・声道の計算機シミュレー ションを行うことになる. Titze がサンプリング周波数 を $1 / \Delta \mathrm{t}=\mathrm{c}$ に選んでいるのは，この辺のところからきて いるのではないかと推測される.

一般に声帯モデルにおいて, 形状と境界条件を指定す ると, その声帯モデルの自励振動しらるモードは自ずと 限定されるので, 仮りに声帯モデルの自励振動モードが 実際の振動モードに類似しているとしても, それだけで は声帯モデルと流体系モデルが適切であるとは一概にい えないのであって，上述のように計算機モデルの動的な 諸特性について, 定量的によく吟味しなければならな い. ちなみに， 1 質量モデルと 2 質量モデルとの比較に おいても， 2 質量モデルが実際に観測されるような上 下方向の位相差を持つ振動モードで振動するから， 1 質 量モデルよりすぐれているといらのではない. 両モデル の上下音響負荷（すなわち, 肺・気管系と声道の音響イ ンピーダンス）に対する自励振動の依存性が本質的に異 なっていて, 実際の発声についてこの依存性を測定して みた結果，2質量モデルのそれとよく一致し，またその 他の諸特性も実測結果とよく一致するがゆえに，2 質量 モデルが取り上げられたのである，また，このような根 拠に基ついて粘膜波状運動の自励振動における本質的意 義が立証され，理解されているのである.

\section{VII. おわりに}

従来発表されている声帯の計算機モデルを, 駆動点イ ンピーダンス形と多質点系形とに大別し, これらのモデ ルの意図するところ, 特長, 問題点等を述べた. また, 声帯モデルと表裏一体をなす声門の空気系モデルについ ては, 声帯モデルの細分化に相応するほどの十分な議論 と吟味がなされていない現状にあるので, 声帯モデルに 見合ら空気系モデルの必要性を述べた. 次に, 声帯の自 励振動機構を固有周波数の縮退の面より説明し, 自励振 動と自由振動との差異を述べた. また, 自励振動におい ては, その動作特性が両側声帯の衝突, 弾性の非線形大 振幅特性, 気流の非線形特性などの振動振幅に対する非 直線性に大きく依存しているのであって,これらの非線
て近似し, 数值計算するときは所要のサンプリング周波 数は(1)式によって定まる（ただし，この場合は縦波のみ 形特性を声帯モデルに適切に組み入れる必要性を述べ た. 最後に, 声帯モデルの自励振動解は計算機による逐 次数值解によらざるを得ないのであって, 波動問題の計 算シミュレーションにおける声帯媒体の分割, サンプリ ング周波数, 計算精度および計算時間などについて述べ た.

音声合成においては, 合成音声の品質, とくに自然性 に対する声帯音源の重要性がしだいに認識されつつあ る. この場合の声帯音源モデルとしては, 主要な動作特 性を具備する範囲で, なるべく簡単なものが望ましいの であって，計算機シミュレーションの手法を含めてより 簡単な音源モデルが追求されるであろう.

他方, 声帯の cover-body 構造, あるいは筋肉の収縮 などとの関連における声帯振動の研究には, 声帯をさら に細分化した多質点系形モデル, とくに有限要素法によ る計算機シミュレーションが適している. この場合を含 めて, 計算機モデルの動作特性は生理的実験データによ って定量的に十分吟味されなければならない.

\section{文献}

1）広戸幾一郎：発声機構の面よりみた喉頭の病 態生 理. 耳鼻臨床, $59: 229 \sim 291,1966$.

2) Ishizaka,K. and Matsudaira,M. : What makes the vocal cord vibrate? 6 th International Congress on Acoustics, $2: \mathrm{B} 9 \sim 12,1968$.

3) Ishizaka,K. and Flanagan, J.L. : Synthesis of voiced sounds from a two-mass model of the vocal cords. Bell System Technical Journal, $51: 1233$ $\sim 1268,1972$.

4) Flanagan, J.L., Lshizaka, K. and Shipley, K. : Synthesis of speech from a dynamic model of the vocal cords and vocal tract. Bell System Technical Journal, $54:$ 485 506, 1975.

5) Flanagan, J.L. and Ishizaka,K. : Automatic generation of voiceless excitation in a vocal-cord/ vocal-tract speech synthesizer. IEEE Trans. on Acoustics, Speech, and Signal Process., $24: 163$ $\sim 170,1976$.

6 ) Hirano, M. : Phonosurgery, Basic and clinical investigations. Otologia (Fukuoka), 21 : Suppl. 1, 1975.

7 ）朱雀保正 : 声帯振動の有限要素法によるシミュレー ション． 日本音響学会講演論文集，189～190, 1971- 
11.

8 ) Titze, I.R. and Talkin, D.T. : A theoretical study of the effects of various laryngeal configurations on the acoustics of phonation. J. of the Acoustical Society of America, 66:60 74, 1979.

9) van den Berg, J., Zantema, J.T. and Doornenbaal, P.Jr.: On the air resistance and the Bernoulli effect of the human larynx. J. of the Acoustical Society of America, $29: 626 \sim 631,1957$.

10) Ishizaka,K. and Matsudaira,M. : Fluid mechanical considerations of vocal cord vibration. SCRL Monograph No. 8, Speech Communications Research Laboratory, 1972.

11）石坂謙三 : 声帯の自励振動機構について. 第12回喉 頭基礎問題研究会資料, 14〜25，1979.

12) Ishizaka, K. : Equivalent lumped-mass models of vocal fold vibration. Vocal Fold Physiology Conference, Kurume, 1980.

13) Titze, I.R. : On the mechanics of vocal fold vibration. J. of the Acoustical Society of America,
$60: 1366 \sim 1380,1976$.

14) Ishizaka, K. and Isshiki, N. : Computer simulation of pathological vocal-cord vibration. J. of the Acoustical Society of America, $60: 1193 \sim 1198$, 1976.

15) Flanagan, J.L. and Landgraph, L.L. : Self-oscillating source for vocal-tract synthesizers. IEEE Trans. on Audio and Electroacoustics, $16: 57 \sim$ 64, 1968.

16) von Gierke, H., Oestreicher, H., Franke, E., Parrack, H. and von Wittern, W. : Physics of vibrations in living tisseus. J. of Applied Physiology, $4: 886 \sim 900,1952$.

17）金子敏郎, 浅野 尚, 三浦徹蔵, 石坂謙三 : 声帯の Biomechanics-stiffness を中心として. 耳鼻臨床： 64 : 増1229 1235, 1971.

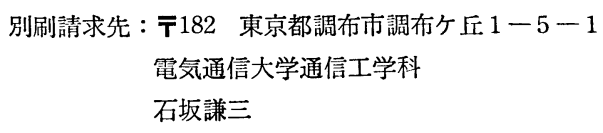

